\title{
NATIONAL REPORT FOR ENGLAND AND WALES
}

Eugenio Vaccari*

\section{Table of Contents}

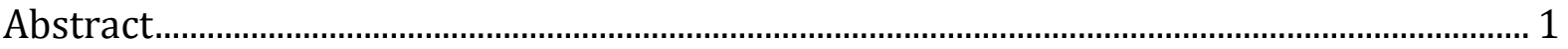

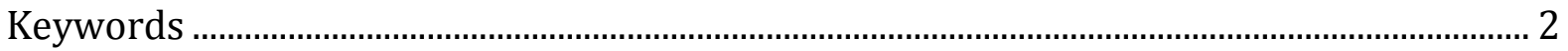

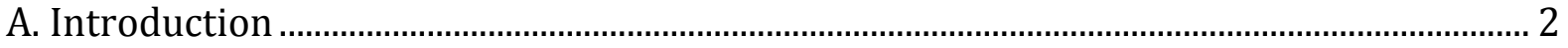

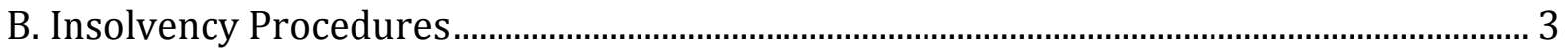

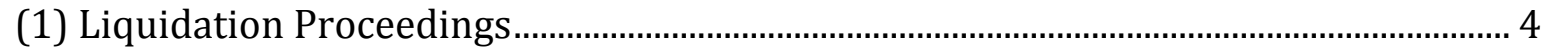

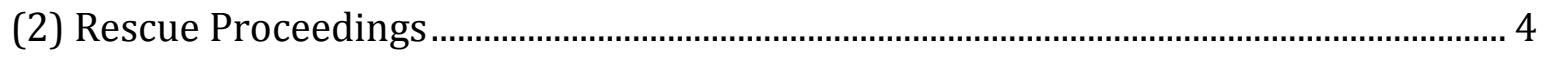

(3) Schemes of Arrangement ……………………………………………………………..... 7

C. Treatment of Executory Contracts …………………………………………………………….

(1) The Effects of Insolvency Proceedings on Executory Contracts .................................... 8

(2) Special Precepts Applicable to Specific Contracts ...........................................................12

(3) Contractual Remedies Negotiated by the Parties in Solvent Times ............................21

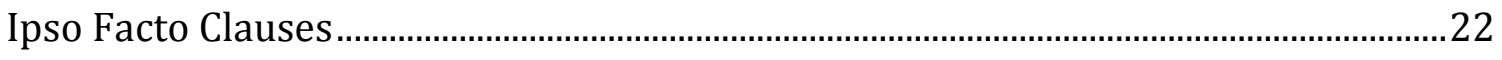

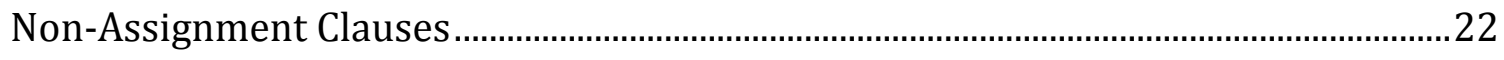

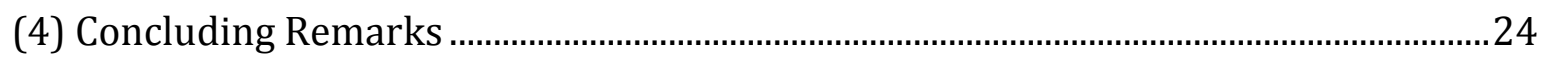

D. Reforms

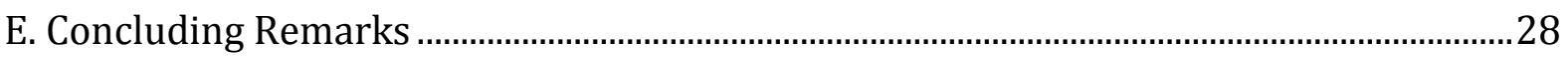

\section{$\underline{\text { Abstract }}$}

This report forms part of a global study undertaking an international comparison of the treatment of executory contracts in the context of insolvency. The introduction covers the history of insolvency law in England and Wales and a description of the procedures 
available to distressed companies. Section C describes the treatment of executory contracts under the law. It explores if and to what extent it has changed over time and whether their treatment is consistent with the pivotal principles of the common law in regards to contracts: party autonomy, freedom of contract and legal predictability. These principles also undergird the English corporate insolvency framework.

Section D extends this consistency exercise to recent reforms of the treatment of these clauses. The final section concludes by observing that the proposed changes to the treatment of executory contracts and termination clauses does not go as far as to reverse the long-established principles that underpin the English corporate and insolvency framework.

\section{$\underline{\text { Keywords }}$}

Executory Contracts; Corporate Insolvency Law; Termination and Assignment of Clauses; Ipso Facto Clauses; Regulatory Reform; England and Wales

\section{$\underline{\text { A. Introduction }}$}

27.1 This report forms part of a global study undertaking an international comparison of the treatment of executory contracts in the context of insolvency. The introduction covers the history of insolvency law in England and Wales, while section B outlines the procedures available to distressed companies to liquidate their assets or restructure their activities. Section $\mathrm{C}$ describes the treatment of executory contracts under the law. It explores if and to what extent it has changed over time and whether their treatment is consistent with the pivotal principles of the common law of contract: party autonomy, freedom of contract and legal predictability. These principles also underpin the English corporate insolvency framework.

27.2 Section D extends this consistency exercise to recent reforms on the treatment of these clauses. The final section concludes by observing that the proposed changes to the treatment of executory contracts and termination clauses does not go as far as to reverse the long-established principles that underpin the English corporate and insolvency framework. 


\section{B. Insolvency Procedures}

27.3 In England, the idea that creditors might act collectively was first introduced by the Bankruptcy Act 1542. The recognition of the limited liability concept, both under the law (Limited Liability Act 1855) and by the judiciary (Salomon's case), ${ }^{1}$ represented a turning point for the development of early insolvency law.

27.4 The stratified and uncoordinated development of rules resulted in a "confused tangle of insolvency laws that was both difficult to operate and prone to manipulation by the unscrupulous". ${ }^{2}$ This situation and the UK's accession to membership of the European Economic Community (EEC) rendered a comprehensive review of the UK insolvency system no longer escapable. ${ }^{3}$

27.5 A Review Committee on Insolvency Law and Practice was appointed in January 1977. Its final report ('Cork Report') 4 marked the beginning of a movement towards stricter penalties against errant directors and increasing emphasis on the rehabilitation of the company. Large parts of its recommendations were transposed into a unified code of insolvency law, the Insolvency Act 1986 (IA 1986 or the Act).

27.6 Due to the general dissatisfaction towards the newly introduced procedures and the low returns for unsecured creditors, the government further amended the law by means of the Enterprise Act 2002 (EA 2002) and the Companies Act 2006 (CA 2006). The first act substantially replaced the administrative receivership with the administration procedure, removed the Crown's status as preferential creditor and introduced the 'prescribed part' for unsecured creditors. ${ }^{5}$ The second statute codified and expanded the directors' duties towards the company, and reversed the Leyland DAF ruling 6 on the priority of liquidation expenses by introducing s.176ZA to the IA 1986.

27.7 This section provides an outline of the main procedures available under the law.

\footnotetext{
${ }^{1}$ Salomon v. A. Salomon \& Co. Ltd [1897] AC 22.

2 V Finch and D Milman, Corporate Insolvency Law: Perspectives and Principles (3 ${ }^{\text {rd }}$ edn, CUP: Cambridge, 2017) 12.

${ }^{3}$ Report of the Cork Advisory Committee (Cmnd 6602, 1976).

${ }^{4}$ Report of the Review Committee in Insolvency Law and Practice (Cmnd 8558, 1982).

${ }^{5}$ Under s.176A of the Act and the Insolvency Act 1986 (Prescribed Part) Order 2003, the "prescribed part" is the part of the proceeds from realising the assets covered by a floating charge which must be set aside and made available to satisfy unsecured debts in liquidation and administration procedures. The rationale for the creation of the prescribed part was to redistribute the funds that would have been allocated to the Crown by reason to its preferential status to all unsecured creditors.

${ }^{6}$ Buchler v Talbot (aka Leyland DAF) [2004] UKHL 9, [2004] 2 AC 298.
} 


\section{(1) Liquidation Proceedings}

27.8 Liquidation is a procedure of last resort, aimed at collecting, realising and distributing the assets and proceeds of the company to its creditors. Liquidation cases still represent the bulk work of insolvency proceedings. ${ }^{7}$ Under the current law, companies can be liquidated in three ways. ${ }^{8}$

27.9 A Members' Voluntary Liquidation (MVL) ${ }^{9}$ can be activated only by the company itself if its directors can issue a statutory declaration that the company is solvent.

27.10 A Creditors' Voluntary liquidation (CVL) ${ }^{10}$ can be triggered only by the company itself whenever it is insolvent and after a resolution of its shareholders (75\% majority). There is no automatic moratorium, but parties may apply to the court for a stay of the proceedings.

27.11 Finally, an Involuntary Liquidation (IL) ${ }^{11}$ may be triggered by the creditors, the directors, the company shareholders and, under certain circumstances, the Department of Trade and Industry (DTI), usually upon proof that the company is unable to pay its debts. ${ }^{12}$ Once the winding up order is made, no action may be started or proceeded against the company without the permission of the court.

\section{(2) Rescue Proceedings}

27.12 Company Voluntary Arrangements (CVAs) ${ }^{13}$ were first introduced by IA 1986. They are agreements between a registered company (not necessarily insolvent), its shareholders and its creditors. The reorganization plan usually involves delayed or reduced debt payment or capital restructuring, but it cannot modify the rights of secured creditors except with the concurrence of the concerned creditor.

\footnotetext{
7 Of the 17,243 companies that entered insolvency in 2017, there were 12,861 creditor voluntary liquidations (74.6\% of total insolvencies) and 2,799 compulsory liquidations (16.2\%) - The Insolvency Service, Insolvency Statistics - October to December 2017 (Q4 2017) 5

<https://assets.publishing.service.gov.uk/government/uploads/system/uploads/attachment_data/file/6 75931/Insolvency_Statistics_-_web.pdf> accessed 8 September 2018.

${ }^{8}$ Companies may also be wound up by the Department of Business, Enterprise and Regulatory Reform (BERR) or the Financial Services Authority (FSA) in the public interest.

9 Part IV, Chapter III IA 1986.

10 Part IV, Chapter IV IA 1986.

11 Part IV, Chapter VI IA 1986.

12 The specific grounds to petition the court are listed in s.122 IA 1986.

13 Part I, ss.1-7B IA 1986 and rules 2.1-2.45, Part II, IR 2016.
} 
27.13 No statutory moratorium is granted, except for small enterprises, ${ }^{14}$ which are given a 28 day stay. ${ }^{15}$ Numerous proposals have been advanced in recent years to extend the moratorium to all companies that filed for a CVA. ${ }^{16}$ One of the proposals was to create a new restructuring moratorium for companies considering restructuring their business, ${ }^{17}$ another one to introduce a new flexible restructuring procedure alongside CVAs. ${ }^{18}$ While CVAs can be used as autonomous procedures, they are frequently complemented with administrations, winding-ups or schemes of arrangement.

27.14 Administration ${ }^{19}$ was first introduced by IA 1986 as an alternative to liquidation. It allows an ailing but not necessarily yet insolvent company, partnership or other entity to conceive a rescue plan while trading. During this period, the company is protected by a moratorium against creditors' actions.

27.15 Any administration has to pursue one of the following three objectives, listed in order of priority in s.3(1), Sch. B1 IA 1986:

1. Rescue the company as a going concern;

2. Achieve a better result for the company's creditors as a whole than would be likely if the company were wound up;

3. Realise the property and distribute the proceeds.

27.16 To make the order, the court has to be satisfied that the company is, or likely to become, unable to pay its debts ${ }^{20}$ and that an administration order is reasonably likely to achieve

\footnotetext{
${ }^{14} \mathrm{~A}$ company is eligible for a moratorium if it meets two or more of the three conditions specified in s.382(3) CA 2006 and it is not excluded from eligibility by s.2(1) and s.3, Sch. A1 IA 1986.

15 The moratorium is regulated by Sch. A1 IA 1986 and was introduced by the Insolvency Act 2000.

16 The Insolvency Service, Encouraging Company Rescue (June 2009) 14-16

<http://webarchive.nationalarchives.gov.uk/20140311023846/http:/www.insolvencydirect.bis.gov.uk/i nsolvencyprofessionandlegislation/con_doc_register/compresc/compresc09.pdf> accessed 8 September 2018.

17 The Insolvency Service, Encouraging Company Rescue (June 2009) 16-19

<http://webarchive.nationalarchives.gov.uk/20140311023846/http:/www.insolvencydirect.bis.gov.uk/i nsolvencyprofessionandlegislation/con_doc_register/compresc/compresc09.pdf > accessed 8 September 2018; The Insolvency Service, A Review of the Corporate Insolvency Framework (May 2016) 10-18 <https://www.gov.uk/government/uploads/system/uploads/attachment_data/file/525523/A_Review_o f_the_Corporate_Insolvency_Framework.pdf> accessed 8 September 2018.

${ }_{18}$ The Insolvency Service, A Review of the Corporate Insolvency Framework (May 2016) 22-27

<https://www.gov.uk/government/uploads/system/uploads/attachment_data/file/525523/A_Review_o f_the_Corporate_Insolvency_Framework.pdf> accessed 8 September 2018.

${ }^{19}$ Sch. B1, IA 1986.

${ }^{20}$ The 'inability to pay its debts' is defined by s.123 IA 1986 as both want of liquidity (i.e. cash flow insolvency) and balance sheet insolvency. In assessing the latter, the court is required to have regard to prospective and contingent liabilities (BNY Corporate Trustee Services Ltd v Eurosail UK 2007-3BL Plc [2013] UKSC 28, [2013] 1 WLR 1408).
} 
the stated purpose. The applicant has to prove on the balance of probabilities test that these thresholds are met. ${ }^{21}$

27.17 Since the admission to the procedure, the company is controlled by an administrator, who is chosen among the licensed insolvency practitioners ('IPs'). Admission may be granted via a court-based procedure (application by the company's creditors to the court) or via an out-of-court route (by the holder of a qualifying floating charge, the company itself or its creditors).

27.18 A sui generis form of administration which continues to gain increasing popularity in recent years ${ }^{22}$ is the pre-pack procedure. These are arrangements for the sale of the debtor's business negotiated with the prospective purchasers and agreed by major creditors prior to the formal commencement of the statutory procedure. The sale is completed shortly after the administration order is made.

27.19 (Administrative) Receivership ${ }^{23}$ has been the most widely used formal insolvency proceeding in the UK. In a receivership, the receiver is demanded to administer the whole, or substantially the whole, of the company's property for the satisfaction of its creditors.

27.20 The importance of this procedure has greatly diminished since the amendments introduced by EA 2002, which prevented the holders of qualifying floating charges created on or after 15 September 2003 from appointing an administrative receiver. According to the Insolvency Service, ${ }^{24}$ in 2017 only two receiverships took place in the United Kingdom (less than $0.1 \%$ of all corporate insolvencies).

\footnotetext{
${ }^{21}$ Re AA Mutual International Insurance Co Ltd [2004] EWHC 2430 (Ch), [2005] 2 BCLC 8.

22 J Armour, 'The Rise of the 'Pre-Pack': Corporate Restructuring in the UK and Proposals for Reform' in RP Austin, Fady JG Aoun (eds), Restructuring Companies in Troubled Times: Director and Creditor Perspectives (Law Publishing Unit: Sydney, 2012). See also the introductory analysis in Teresa Graham CBE, Graham Review into Pre-pack Administration (The Insolvency Service, 2014), <https://www.gov.uk/government/publications/graham-review-into-pre-pack-administration> accessed 8 September 2018.

23 Part III, IA 1986.

24 The Insolvency Service, Insolvency Statistics - October to December 2017 (Q4 2017) 5 <https://assets.publishing.service.gov.uk/government/uploads/system/uploads/attachment_data/file/6 75931/Insolvency_Statistics_-_web.pdf> accessed 8 September 2018.
} 


\section{(3) Schemes of Arrangement}

27.21 Schemes of arrangement (SoA) ${ }^{25}$ present an alternative to formal insolvency proceedings and are regulated under general, company law. SoAs facilitate entrance of a company into a compromise or arrangement with its creditors (including secured ones).

27.22 Under English law, a company is entitled to enter into a scheme if it is capable of being wound up in England and Wales. This is possible if the company has "sufficient connection" with those territories, a concept that courts have construed in a very broad manner. ${ }^{26}$

\section{Treatment of Executory Contracts}

27.23 This section describes the rules applicable to executory contracts ${ }^{27}$ when the debtor enters into any type of formal insolvency proceedings. ${ }^{28}$ It reports on the special precepts applicable to contracts considered worthy of peculiar consideration by the legislator and on the validity of contractual remedies negotiated by the parties in solvent times.

27.24 The focus of this paper is on the evolutionary aspect of the law, to evaluate if insolvency rules have been applied in a manner consistent with the principles of party autonomy, ${ }^{29}$

\footnotetext{
25 Part 26, CA 2006.

${ }^{26}$ In Re Van Gansewinkel Groep BV [2015] EWHC 2151 (Ch), [2015] Bus LR 1046 the court was required to determine if it had jurisdiction to sanction schemes of arrangement in respect of Dutch and Belgian companies with no establishment in England. It held that a sufficient connection had been shown in that the governing law of all the finance documents was English. Also: Re Hibu Group Ltd [2016] EWHC 1921 (Ch).

${ }^{27}$ For the purposes of this paper, executory contracts are onerous contracts under which neither party has performed any of its obligations, or both parties have partially performed their obligations to an equal extent - See International Accounting Standards (IAS) 37, Provisions, Contingent Liabilities and Contingent Assets (16 September 2009)

<http://ec.europa.eu/internal_market/accounting/docs/consolidated/ias37_en.pdf> accessed 8 September 2018.

${ }^{28}$ With reference to SoAs, since they are de facto contracts sanctioned by the court, parties are free to determine their content; no special statutory rule applies to them.

${ }^{29}$ The cardinal importance of the principle of autonomy of the parties in common law is often presumed: see JN Adams and R Brownsword, 'The Ideologies of Contract' (1987) 7 Leg. Stud. 205, 208-10. Autonomy was clearly placed to the fore by Diplock LJ in Photo Production Ltd v Securicor Transport Ltd [1980] AC 827 (HL), at 848: "A basic principle of the common law of contract [...] is that parties to a contract are free to determine for themselves what primary obligations they will accept". It is also reinstated in article 3 of the Regulation (EC) No. 593/2008 of the European Parliament and of the Council of 17 June 2008 on the law applicable to contractual obligations (Rome I) [2008] OJ L 177/6, which applies to contracts concluded on or after 17 December 2009 all over Europe (with the exception of Denmark). For a detailed analysis of the scope of this principle, see S Worthington, 'Common Law Values: The Role of Party Autonomy in Private Law' (June 1, 2015) University of Cambridge Faculty of Law Research Paper No. 33/2015 <https://ssrn.com/abstract=2620191> accessed 8 September 2018.
} 
freedom of contract ${ }^{30}$ and legal predictability of judicial decisions. ${ }^{31}$ These principles represent the backbone of the entire English legal system.

\section{(1) The Effects of Insolvency Proceedings on Executory Contracts}

27.25 The opening of formal insolvency proceedings does not in itself affect the validity of ongoing contracts. ${ }^{32}$ It is, however, unlikely that official receivers and liquidators will continue to perform all of the debtor's duties, especially when the company has no prospects of revival. In some large cases, such as the collapse of Carillion, third parties and the government may step in and use their funds to ensure that the executory agreements (in this case, public procurement contracts) continue to be performed. ${ }^{33}$

27.26 If contracts continue to be performed, payments for obligations performed after the company entered into liquidation or administration are ranked as an expense of the procedure, and they are paid in priority over other creditors despite the fact that they arose out of contracts signed before the filing of the insolvency petition. ${ }^{34}$

27.27 Game Station ${ }^{35}$ shows a significant deviation from previous case law. ${ }^{36}$ In this case, it was held that, where property leased by a company was retained during the administration

\footnotetext{
30 The pivotal significance of the principle of freedom of contract emerges from different sources. One of the most often cited is the decision in Printing and Numerical Registering Co v Sampson (1874-75) LR 19 Eq. 462, 465 Ct of Chancery. On that occasion, Sir George Jessel, the Master of the Rolls, stated that ' [...] if there is one thing more than another public policy requires it is that men of full age and competent understanding shall have the utmost liberty of contracting, that their contracts when entered into freely and voluntarily shall be held sacred and shall be enforced by Courts of Justice. Therefore, you have this paramount public policy to consider - that you are not likely to interfere with this freedom of contract'. ${ }^{31}$ The terms 'predictability' and 'certainty' are frequently used as synonyms, but this chapter prefers to rely on the less assertive term, as it has already been observed that "in this world nothing can be said to be certain, except death and taxes". For the value of predictability in the law, see R Goode, "The Codification of Commercial Law' (1988) 14 Monash U. L. Rev. 135, 150.

${ }^{32}$ It is possible, however, to seek a declaration that a contract has been terminated by frustration, a circumstance, which occurs only if the commencement of an insolvency proceeding by one of the contracting parties determines a significant modification of the rights and obligations contemplated at the time of its execution. See National Carriers Ltd v Panalpina (Northern) Ltd [1981] AC 675 (HL) and Tradigrain Do Brasil v Ace Insurance SA-NV [2002] EWHC 2110 (Comm).

${ }^{33} \mathrm{O}$ Gill, 'The government is paying millions of pounds a day to keep Carillion public sector projects going' City A.M. (23 January 2018) <http://www.cityam.com/279297/carillions-collapse-costing-taxpayergbp54m-day> accessed 7 March 2018.

${ }^{34}$ Re Lundy Granite Co. [1870-1871] LR 6 Ch App 462 (CA). This exception has been encapsulated in rule 4.218(3)(a)(ii) of the Insolvency Rules 1986, now replaced by rule 6.42(4)(a) for creditors' winding up and rule 7.108(4)(a)(ii) for winding up by courts in the Insolvency Rules 2016. With reference to administration proceedings, the same principle applies by virtue of rule 3.51(1) of the Insolvency Rules 2016, which replaces rule 2.67(1) of the Insolvency Rules 1986.

${ }^{35}$ Sub nomine Jervis v Pillar Denton Ltd [2014] EWCA Civ 180, [2015] Ch. 87.

${ }^{36}$ Goldacre (Offices) Ltd v Nortel Networks UK Ltd (In Administration) [2009] EWHC 3389 (Ch), [2010] Ch. 455; and Leisure (Norwich) II Ltd v Luminar Lava Ignite Ltd (In Administration) [2012] EWHC 951 (Ch), [2014] Ch. 165.
} 
procedure, the creditor was entitled to full payment of the outstanding rent as an expense in the administration even if the expenses became due before the company entered into administration.

27.28 The relevance of this decision, however, should not be overstated. In Game, it is conceded that the debtor entered into insolvency after the contractual rent had fallen due. However, that instalment would have covered the quarter after the appointment of the administrators. Therefore, the Court of Appeal relied on equitable principles to hold that the portion of the rent that covers the post-appointment occupation of the property shall be considered as an expense of the administration.

27.29 This apportionment put an end to an established practice of game playing. ${ }^{37}$ It has been highly praised by commentators ${ }^{38}$ as it prevents both the proprietor and the insolvent estate from being disproportionately burdened by liabilities. ${ }^{39}$ While the legislature omitted to codify the decision in Game in the Insolvency Rules 2016 (thus not making life easier for practitioners), ${ }^{40}$ it is unlikely that this approach will soon be overturned. ${ }^{41} \mathrm{At}$ the same time, it is equally likely that courts will continue to adopt a restrictive interpretation of the use of their equitable powers in similar circumstances. ${ }^{42}$

27.30 The assumption of existing liabilities or continuation of contractual duties cannot be inferred in the following circumstances:

1. Where the creditor or the debtor can expressly or implicitly repudiate the contract or decline the performance offered by the counter-party;

2. Where the parties have negotiated a provision to terminate the contract in the event of insolvency;

\footnotetext{
37 V Finch and D Milman, Corporate Insolvency Law: Perspectives and Principles (3 $3^{\text {rd }}$ edn, CUP: Cambridge, 2017) 345.

${ }^{38}$ A Sharp and others, 'Game Over: Rent as an Administration Expense on a Pay As You Go Basis' (2014) 7 C.R. \& I. 57; J Verrill and P Pal, 'Cherry Picking, Break Dancing and Gaming' (2014) 4 JIBFL 227; J Bannister and J Dabbs, 'Game: A Victory for Common Sense?' (2014) 27(5) Insolv. Int. 74.

${ }^{39}$ It is still debatable whether the Game case allows rents to be apportioned not only by time but also by space. The author is sceptical about the latter, as it would result in a unilateral ex post amendment of a contract freely entered into by the parties, while English judges have always tried to preserve party autonomy to the highest possible extent: G Fetherstonhaugh, 'An Adventure in Time and Space' (2017) 1716 E.G. 63.

${ }^{40} \mathrm{~J}$ Kaffash, 'Where Next for IPs?' (2014) 152(1449) Accountancy 8; C Shuttleworth and S Lynch, 'Game On: Tackling the Impact of Game - A Look at the Clinton Cards Liquidation' (2016) 9(4) C.R. \& I. 137.

${ }^{41} \mathrm{~S}$ Gray and T Cox, 'The Insolvency Merry-Go-Round' (2017) 1705 E.G. 63, 64.

42 Laverty v British Gas Trading Ltd [2014] EWHC 2721 (Ch), [2015] 2 All ER 430; Re Birchall (A Bankrupt) [2015] EWHC 1541 (Ch), [2017] 1 WLR 667.
} 
3. Where contracts can be disclaimed as onerous. ${ }^{43}$

27.31 Absent any statutory obligations to perform, creditors and suppliers may lawfully withdraw their performance unless the debtor pays for the outstanding invoices. ${ }^{44}$ This outcome is particularly taxing for the office-holder, since paying for the outstanding invoices usually requires the approval of the creditors' committee, as well as breaching the pari passu principle of distribution among unsecured creditors. ${ }^{45}$

27.32 However, courts have restricted the creditors' power to withdraw performance. In $H M R C$ $v$ Wimbledon $F C{ }^{46}$ the Court of Appeal held that such a course of action could be taken only "in the most exceptional circumstances".

27.33 Conversely, office-holders may equally decline to procure performance if the buyer has no property rights on the goods manufactured or services offered by the debtor. However, creditors may challenge the office-holder's rejection, thus further reducing the power of the insolvent estate to discontinue executory contracts even if they traded the contract at a loss. ${ }^{47}$

27.34 Additionally, para 74, Sch. B1 of the Act gives the creditors the power to challenge an administration's decision if conspicuously unfair to a particular contractor or creditor. Nevertheless, courts are reluctant to use these equitable powers if performance of the contract would be to the detriment of the creditors as a whole and unsecured creditors would be treated according to their legal rights in insolvency.48

\footnotetext{
${ }^{43}$ ss.178-182 IA 1986. See generally IF Fletcher, The Law of Insolvency $\left(5^{\text {th }}\right.$ edn, Sweet \& Maxwell: London, 2017) [24-003]-[24-013].

${ }^{44}$ Leyland DAF Limited v Automotive Products Plc [1993] B.C.C. 389 (CA): an unpaid seller who refuses to supply further goods to the company until the company meets its debts was not abusing a dominant position.

${ }^{45}$ Suppliers are usually unsecured creditors. However, their strong bargaining position may allow them to obtain a higher return for their claims.

${ }^{46}$ Inland Revenue Commissioners v Wimbledon Football Club Ltd [2004] EWCA Civ 655, [2004] BCC 638: a proposed CVA did not infringe insolvency rules even if certain unsecured creditors were to be paid in full whereas the Inland Revenue as a preferential creditor was only to receive a dividend of 30 pence in the pound when the proceeds of sale were distributed under the arrangement.

${ }^{47}$ Land Rover Group Ltd v UPF (Uk) Ltd (in Administrative Receivership) [2002] EWHC 2128 (QB), [2003] 2 BCLC 222.

${ }^{48}$ Joint Administrators of Rangers Football Club Plc, Noters [2012] CSOH 55.
} 
27.35 Similarly, liquidators (but not administrators) ${ }^{49}$ in England and Wales can unilaterally (i.e. without the need for a court sanction) ${ }^{50}$ disclaim onerous property pursuant to 5.178 IA 1986.51 The notion of 'onerous property' includes any:

a) unprofitable contract;

b) other unsaleable or not readily saleable property; and

c) property that may give rise to a liability to pay money, or perform an onerous act on the debtor. ${ }^{52}$

27.36 There is no time limit on the liquidator to exercise the right of a disclaimer, but the other contracting party may solicit a decision by asking for a clear determination within a 28day period. If the liquidator does not exercise this right within the statutory period, he/she loses the right to terminate (i.e. repudiate) the contract unilaterally by notice, thus enabling the counterparty to elect to hold the contract open for future performance. 53

27.37 Where the contract is repudiated, the non-breaching party has the right to ask for damages for non-performance. These claims rank as unsecured entitlements against the insolvent estate. ${ }^{54}$

27.38 The power to disclaim onerous contracts has been interpreted restrictively where the decision to divest could have potentially negative consequences for the environment,, 5 but courts have now established that liquidators can disclaim environmental costs and waste management licences. ${ }^{56}$ Despite the existence of the "polluter pays" principle, ${ }^{57}$ there is no statutory or equitable rule that can force the liquidator/polluter to pay even where there is no money to meet environmental liabilities. ${ }^{58}$ These disclaimer powers

\footnotetext{
${ }^{49}$ s.178(2) IA 1986 and Re P\&C and R\&T (Stockport) Ltd [1991] B.C.C. 98 (Ch).

${ }^{50}$ Firmin v Aardvark Tmc Ltd [2013] EWHC 1774 (Ch).

${ }^{51}$ For an exhaustive analysis: IF Fletcher, The Law of Insolvency (5 ${ }^{\text {th }}$ edn, Sweet \& Maxwell: London, 2017) 742-747.

52 s.178(3) IA 1986.

${ }^{53}$ s.178(5) IA 1986 and Stead, Hazel \& Co. v Cooper [1933] 1 KB 840.

54 s.186 IA 1986.

${ }^{55}$ Re Mineral Resources Ltd [1999] 1 All E.R. 746, where Neuberger LJ held that the broad scope of the powers conferred by s.178 IA 1986 could not prevail over special provisions in the law, such as s.35(11) of the Environmental Protection Act 1990.

${ }^{56}$ Re Celtic Extraction Ltd (in liq.) [2001] Ch. 475 (CA) (which was effectively an appeal from Re Mineral Resources); Environment Agency v Hillridge Ltd [2003] EWHC 3023 (Ch), [2004] 2 BCLC 358.

${ }^{57}$ Environmental Protection Act 1990 enacted to give effect to Council Directive 72/442/EEC of 15 July 1975 on Waste [1975] (OJ L 194).

${ }^{58}$ Re Celtic Extraction Ltd (in liq.) [2001] Ch. 475 (CA) [39]. On this topic, see generally: H Hill, 'Bankruptcy vs Environmental Protection: A Case Study in Normative Conflict' (1998) 11 C.J.L.J. 245; C Shelbourn, 'Waste Management and the Insolvent Company' (2000) J.P.L. 134; J Armour, 'Who Pays When Polluters Go Bust?' (2000) 11 L.Q.R. 200; A Keay and P de Prez, 'Insolvency and Environmental Principles: A Case
} 
can be used in conjunction with administration proceedings to facilitate the sale of profitable parts of a distressed company, 59 thus giving rise to dubious rescue practices for their potential implications for public health and unfair competition.

27.39 Finally, courts held that the liquidator's power to disclaim a lease (s.179 IA 1986) could only be challenged if the liquidator acted with mala fide or the decision was perverse. ${ }^{60} \mathrm{~A}$ liquidator cannot disclaim a contract merely because the company could have made, or could make a better bargain. ${ }^{61}$

27.40 Liquidators do not have similar powers in Scotland. In Joint Liquidators of the Scottish Coal Co Ltd, Noters ${ }^{62}$ the Scottish Court of Session held that a debtor could not divest the company of a real right in land by unilateral disclaimer whereby the land would become bona vacantia and fall to be administered by the Crown because of the monthly costs of complying with the environmental statutory obligations.

27.41 Overall, it appears that deviations from the 'continuation' rule do not seriously infringe the general principles mentioned above. The most problematic deviation is the right to disclaim onerous contracts. Despite its potentially wide scope, courts have consistently checked that these powers are not used in an inequitable manner. Nevertheless, their existence represents a serious preach to the principles of party autonomy and freedom of contract. Creditors are not without remedies, both procedural and substantial in nature, which ensure a certain degree of protection to their interests.

\section{(2) Special Precepts Applicable to Specific Contracts}

27.42 Beside the above-mentioned general rules, the English legislator has also introduced special precepts for nominated contracts. These may result in significant exceptions from

\footnotetext{
Study in a Conflict of Public Interests' (2001) 3(2) Env. L. Rev. 90; A Keay and P de Prez, 'Should Insolvent Companies Pay? The Search for Environmental Principle' (2001) 9(1) Env. Liability 11; B Mamutse and V Fogleman, 'Improving the Treatment of Environmental Claims in Insolvency' (2013) 5 J.B.L. 486; B Mamutse, 'Environmental Liabilities in Insolvency - An Area Ripe for Reform?' (2016) 8(3) International Journal of the Law in the Built Environment 243; IL Fannon, 'Managing Waste: The Gap Between the EU Directives and Corporate Law in Member States - A Mess of Case Law Needing Clean-up' (2016) 24(6) Env. Liability 203.

${ }^{59}$ See the case of Re UK Coal Operations Ltd [2013] EWHC 1774 (Ch), [2014] 1 BCLC 471, as described by B Mamutse, 'Environmental Liabilities in Insolvency - An Area Ripe for Reform?' (2016) 8(3) International Journal of the Law in the Built Environment 243, 245.

${ }^{60}$ Re Hans Place Ltd [1992] B.C.C. 737 (Ch); Mahomed v Morris (No. 2) [2001] B.C.C. 233 (CA).

${ }^{61}$ Re SSSL Realisations (2002) Ltd [2006] EWCA Civ 7, [2006] Ch. 610. See in particular [36]-[54] for the principled approach to disclaiming unprofitable properties.

${ }^{62}$ Joint Liquidators of the Scottish Coal Co Ltd, Noters [2013] CSIH 108.
} 
the established rule that contracts and their clauses are unaffected by the opening of an insolvency procedure.

27.43 This sub-section covers these statutory exceptions to investigate if and to what extent they represent a deviation from an established tradition of reliance on legal predictability, party autonomy and freedom of contract.

27.44 With reference to sale contracts, the law recognises that the buyer or seller has a right to specific performance against the insolvent estate when the applicant has a proprietary right over the $\operatorname{good}(\mathrm{s})$. This is the case, for instance, of a contract of sale of land concluded before the opening of insolvency proceedings, as the property in this case passes in equity when contracts are exchanged, subject to the payment of the purchase price. ${ }^{63}$

27.45 In all other sale contracts, it is essential to look at the objective intention of the parties ${ }^{64}$ to determine on one hand if the insolvent debtor has the right to decline to procure performance and, on the other, if the creditor can demand specific performance. If the sale or the executory contract between the parties has been conducted under an agreement incorporating a retention of title clause, 65 the debtor is not free to dispose of the goods, 66 as this would give the insolvent administrators the power to override third parties' proprietary rights.

27.46 The same rule applies also when parties place money or assets in a trust, 67 or when they agree on money being used for a specific purpose (e.g. 'purpose trust' or 'project bank accounts'). ${ }^{68}$ However, the intention of the parties shall result in a declaration that brings certainty not only to the existence of, but also the scope and the assets subject to the

\footnotetext{
${ }^{63}$ Law of Property (Miscellaneous Provisions) Act 1989 and Pearce v Bastable's Trustee In Bankruptcy [1901] 2 Ch. 122, applied by Capital Prime Properties Plc v Worthgate Ltd (in Liq) [2000] B.C.C. 525 (Ch), where the court held that the disclaimer offered by s.178 IA 1986 could operate only to release from onerous contractual obligations, but not from recovering the ownership of a real estate property. ${ }^{64}$ Smith v Hughes [1870-71] L.R. 6 Q.B. 597; Destiny 1 Ltd v Lloyds TSB Bank PIc [2011] EWCA Civ 831. ${ }^{65}$ Aluminium Industrie Vaassen BV v Romalpa Aluminium Ltd [1976] 2 All E.R. 552. For an illuminating analysis of these clauses: RM Goode, Proprietary Rights and Insolvency in Sales Transactions $\left(3^{\text {rd }}\right.$ edn, Sweet \& Maxwell: London, 2009), Ch. 5; and IF Fletcher, The Law of Insolvency (5 $5^{\text {th }}$ edn, Sweet \& Maxwell: London, 2017) 800-802.

${ }^{66}$ Hachette UK Ltd v Borders (UK) Ltd [2009] EWHC 3487 (Ch).

${ }^{67}$ Re Kayford Ltd [1975] 1 All ER 604; Re Fleet Disposals Ltd [1995] BCLC 345.

${ }^{68}$ Project Bank Accounts (PBAs) are ring-fenced accounts that have trust status where payments are made directly and simultaneously by a client to members of its supply chain down to second tier suppliers.
} 
trust. ${ }^{99}$ Additionally, any trust can be challenged if its creation offended the antideprivation rule or in circumstances where transaction avoidance rules apply. ${ }^{70}$

27.47 S.43(3), Sch. B1 of the Act entitles the insolvent estate in an administration procedure to reject the request submitted by the buyer for repossession of the goods sold under a hirepurchase agreement. For the purposes of the section, the notion of 'hire purchase agreement' includes conditional sale, chattel leasing and retention of title agreements. ${ }^{71}$

27.48 Courts have imposed limits on the right of the administrator to reject a request of repossession of goods, ${ }^{72}$ particularly when the procedure appears as a delaying tactic, a "bogus". 73

27.49 Accordingly, the author believes that this statutory trade-off between the interests of all of the affected parties respects the principles underpinning the general law of contract and the corporate insolvency framework. The limited equitable exceptions recognised following Berkeley Applegate do not change the overall valuation of the institute, as these deviations apply only when it appears manifestly unfair and unjust to leave the claimant without remedies. ${ }^{74}$

27.50 In the author's view, the same rationale can be found also with reference to other statutory deviations from the established rule on the treatment of executory contracts.

27.51 This is the case, among others, of the treatment of insurance contracts. Originally, if a person obtained a judgment for damages against a company and that company - despite carrying an insurance against the type of damage - went into liquidation, the claimant could not recover directly from the insurer. The claimant could only place a claim as an unsecured creditor against the insolvent estate, with no special interest in the insurance monies. ${ }^{75}$

\footnotetext{
${ }^{69}$ Re Goldcorp Exchange [1995] 1 AC 74 (PC).

${ }^{70}$ English law applies even to cases where the beneficiaries of the trust are incorporated in a jurisdiction that did not recognise the institution of a trust or a division between legal and equitable property interests, such as Saudi Arabia: Akers v Samba Financial Group [2017] UKSC 6, [2017] AC 424.

${ }^{71}$ S.111(1), Sch. B1 IA 1986.

72 Re Atlantic Computer Systems Plc (No. 1) [1992] Ch. 505 (CA).

${ }^{73}$ Bernard Sport Surfaces Ltd v Astrosoccer4U Ltd [2017] EWHC 2425 (TCC); [2018] BCC 147 [15].

${ }^{74}$ Re Berkeley Applegate (Investment Consultants) Ltd (No. 2) [1989] 1 Ch 32: office-holders who have carried out substantial works for assets that in the end did not belong to the company were entitled to remuneration over the concerned assets. Also, Gillan v HEC Enterprises Ltd [2016] EWHC 3179 (Ch); [2017] 1 BCLC 340.

${ }^{75}$ Re Harrington Motor Co Ltd [1928] 1 Ch 105.
} 
27.52 This rule has been reversed by means of the Third Party (Rights Against Insurers) Act 1930, which gave the power to creditors to claim the indemnity directly from the insurer. ${ }^{76}$ The Third Party (Rights Against Insurers) Act 2010, which entered into force only in 2016 after further amendments made by the Insurance Act 2015 (SI 2016/550), addressed some of the shortcomings of the 1930 Act, while retaining the possibility for the claimant to demonstrate its rights and obtain the distribution directly from the insurer in a single proceeding, ${ }^{77}$ thus circumventing insolvency rules on the distribution of proceeds.

27.53 This statutory choice is not in conflict with the principles mentioned above. On the contrary, the opposite solution suggested by the judiciary in Harrington would have resulted in an unpredictable and unjust windfall to the advantage of the insolvent estate.

27.54 The same considerations apply in regards to the protection afforded to pension contracts. The legislator has protected employees' entitlements to their wages with a system of statutory liabilities, protected funds ${ }^{78}$ and independent authorities. ${ }^{79}$ As these are monies of the company administered for the benefit of third parties, it is only appropriate that these third parties should be entitled to exercise their contractual rights even in insolvency scenarios.

27.55 For other contracts such as building or construction contracts ${ }^{80}$ and IP, domain name and licensing contracts, the law does not prescribe fixed solutions. In these cases, courts adopt a case-by-case approach to determine if the provisions negotiated by the parties in solvent times result in a breach of equitable principles. ${ }^{81}$

\footnotetext{
${ }^{76}$ Additionally, courts have found that any clause in an insurance contract, which provide that an indemnity would cease on a company's insolvency, represent a breach of the anti-deprivation principle, as it deprives the administrator (and, potentially, third parties) of an asset of the company: Mayhew $v$ King [2011] EWCA Civ 328, [2011] Bus LR 1327.

${ }^{77}$ BAE Systems Pension Funds Trustee Ltd $v$ Bowmer and Kirkland Ltd [2017] EWHC 1200 (TCC).

${ }^{78}$ Pension Protection Fund (PPF), which became operational on 6 April 2005 and is regulated by the Pensions Act 2004, Part 2. D Pollard, 'Pensions and TUPE' (2005) 34(2) ILJ 127; D McCarthy and A Neuberger, 'The Pension Protection Fund' (2005) 26(2) Fiscal Studies 139.

${ }^{79}$ Pension Regulator (PR), which equally became operation on 6 April 2005 and is regulated by the Pensions Act 2004, Part 1.

80 Other jurisdictions such as Argentina, on the other hand, have introduced measures to protect buyers.

${ }^{81} \mathrm{C}$ Cooke and others, 'National Report for England' in D Faber and others (eds), Treatment of Contracts in Insolvency (OUP: Oxford, 2013) 161.
} 
27.56 There are cases, however, where the balance struck by the legislation can prove more problematic to justify in conceptual terms.

27.57 One of them is the matter of "utility" and essential contracts. Under s.233 IA 1986, as amended by the Insolvency (Protection of Essential Supplies) Order 2015, private utility suppliers (including landlords) and statutory undertakers of gas, electricity, water and communication services cannot compel future performance to the payment of debts incurred before the commencement of insolvency proceedings. ${ }^{82}$

27.58 This restriction, whose introduction was recommended in the Cork Report, ${ }^{83}$ can potentially promote rescue activities. However, this is only made possible at the expense of one of the pillars of contract law, i.e. the principle of party autonomy. Still, the changes may be less radical than they appear.

27.59 In fact, despite the inclusion of private utility providers and the use of a wide notion for 'communication services', ${ }^{44}$ the government deliberately rejected the calls (in particular, from rescue professionals and practitioners) to extend the protection to all those contracts that the debtors claimed to be essential to the continuation of their business. In fact, no obligations of such kind have been extended to card payment providers and the list of "essential suppliers" has been made exhaustive. 85

27.60 However, the complexities of market relations may render this list inadequate for some businesses, which may alternatively only rely on the discretionary and equitable powers of the courts to obtain protection in the cases not mentioned in the law. English courts have insofar proven willing to comply, for instance in extending the effect of the s.233 order to cross-border disputes. ${ }^{86}$ Even when they dismissed the request to compel a supplier to provide essential goods unless pre-insolvency debts were paid, they hinted at

\footnotetext{
${ }^{82}$ ss.372 and 372(A) IA 1986 extend this framework to individual voluntary arrangements (IVAs). The 2015 amendments apply only to contracts entered into on or after 1 October 2015.

83 Report of the Review Committee on Insolvency Law and Practice (Cmnd 8558, 1982) Ch. 33, esp. paras 1451-1462.

${ }^{84}$ S.233(3)(d) and (5)(d) IA 1986.

85 This solution sits at odds with the recommendation in the Cork Report, where it is possible to read that "the situation [that justifies the introduction of the law] is not confined to public utilities. It may arise whenever there is an outstanding account with a private supplier": Report of the Review Committee on Insolvency Law and Practice (Cmnd 8558, 1982) Ch. 33, para 1453.

${ }^{86}$ Official Receiver v Sahavitiya Steel Industries Plc [2015] EWHC 2877 (Ch), [2016] BCC 456. This outcome is even more striking when it is considered that the application was heard in private and the order made without notice.
} 
reaching a different conclusion should the supplier's actions prove unfair or unreasonable, or amount to an abuse of a dominant position. ${ }^{87}$

27.61 Creditors still benefit from significant protections, as suppliers can still make it a condition of the supply process that office-holders personally guarantee future (but not pre-petition) payments. ${ }^{88}$ However, if the contract is terminated (e.g. by mutual agreement) but the supply continues under a "deemed contract", the office-holder is not personally liable for the payments and the mere fact of continuing supply does not entitle the supplier to priority of payment over secured creditors. ${ }^{89}$

27.62 A further restriction applicable to essential suppliers has been introduced by s.233A of the Act. According to this provision, any insolvency-related term of a contract for the supply of essential goods and services that seeks to either terminate or vary the terms of the contract where the customer entered into a CVA or administration procedure is automatically rendered void.

27.63 Nevertheless, while courts could void insolvency-related contractual terms to charge higher prices or terminate the contract by reason of the debtor's insolvency filing, the supplier can still rely on:

a) non-insolvency-related contractual terms for the purpose of terminating the contract, such as changes in consumption, or downgraded credit ratings; and

b) insolvency-related terms insofar as they relate to other insolvency (such as bankruptcy or liquidation) and restructuring (e.g. currently schemes of arrangements) procedures.

27.64 Moreover, termination is still possible:

1) if the cause of the termination is an event that occurred after the commencement of the insolvency procedure;

2) if charges incurred after the company entered into administration or CVA are not paid for a period exceeding 28 days when the first payment was due;

\footnotetext{
87 Leyland DAF Ltd v Automotive Products PIc [1993] BCC 389 (CA).

88 s.233(2) IA 1986.

${ }^{89}$ Laverty v British Gas Trading Ltd [2014] EWHC 2721 (Ch), [2015] 2 All ER 430.
} 
3) if the office-holder does not provide a personal guarantee for the payment of essential supplies received after the commencement of the procedure; 90 or

4) when the office-holder or the court consent to the termination. ${ }^{91}$ Courts usually authorize termination when they are satisfied that the continuation of the contract would cause undue hardship to the supplier.

27.65 While it is extremely challenging for a supplier to prove the existence of a relevant level of undue hardship, creditors can rely on a variety of mechanisms to protect their interests. Additionally, it is unlikely that the debtor will default on a payment for the supply of products if the company really deems that the contract is valuable and essential for the turnaround of the insolvent estate. ${ }^{92}$

27.66 In this context, the outright exclusion of the voidability of insolvency-related clauses in liquidation procedures is troublesome to justify in conceptual terms, as there may be liquidation procedures where continuation of the business for a limited time is required to orderly sell the assets.

27.67 Similar problematic considerations might also be found in leasing or rental contracts. Upon the opening of formal proceedings, the insolvent lessee can disclaim a lease where the property is not necessary for the company to continue its business, ${ }^{93}$ except when the lessee's use of land is governed by statutory permits. ${ }^{94}$ Conversely, the lessor may not force re-possession, except with the permission of the court. ${ }^{95}$ The insolvency of the lessor does not affect the enforceability of the leasing or rental contract.

27.68 It is undeniable that the autonomy of the solvent lessor is significantly curtailed. However, their substantive rights (and, primarily, the right to remuneration) are protected and the compression of their autonomy is justified in light of opposing principles (legal predictability and promotion of rescue of viable businesses).

\footnotetext{
90 s.233A(5) IA 1986.

${ }^{91}$ s.233A(4) IA 1986.

92 As it happened before the enactment of IA 1986: Wellworth Cash \& Carry (North Shields Ltd) v North Eastern Electricity Board [1986] 2 BCC 99 (Ch).

${ }_{93}$ Schroder Exempt Property Unit Trust v Birmingham City Council [2014] EWHC 2207 (Admin), [2014] BCC 690.

${ }_{94}$ Joint Liquidators of the Scottish Coal Co Ltd, Noters [2013] CSOH 124.

${ }_{95}$ Metro Nominees (Wandsworth) (No. 1) Ltd v Rayment [2008] BCC 40.
} 
27.69 Autonomous considerations deserve those contracts, whose special regulation is justified on one hand by their particular content and, on the other, by the interference with European binding provisions. This is the case of employment contracts and financial contracts.

27.70 Following the general rule on the treatment of executory contracts, the opening of an insolvency procedure does not cause the termination of employment contracts. Exceptions include liquidations aimed at terminating the activity of the company ${ }^{96}$ and cases where there are enforceable termination clauses in the employment contract.

27.71 Employment contracts are potentially affected by the EU Business Transfers Directive ('2001 Transfer Directive'),97 enforced in the United Kingdom by means of the Transfer of Undertakings (Protection of Employment) Regulations 2006 (SI 2006/246) ('TUPE Regulations' $)^{98}$ as amended by the Collective Redundancies and Transfer of Undertakings (Protection of Employment) (Amendment) Regulations 2014 (SI 2014/16).

27.72 The European and British statutes preserve the validity of employment contracts when a business or undertaking, or one of their units, is transferred to a new employer. The original directive and the pre-2006 TUPE affected transfers both in non-rescue insolvency and in non-insolvency cases, an interpretation confirmed by the ECJ.99 The established common law approach that a business transfer terminated all employment contracts $^{100}$ was subverted. However, the most recent 2001 Transfer Directive (art. 5) and TUPE Regulations (regulation 8) clarified that the protective measures do not apply to certain insolvency proceedings. Autonomy of the parties has been restored.

27.73 Under the current version of TUPE Regulations, whenever insolvency proceedings are not opened with a view to liquidation of the assets of the transferor, employment

\footnotetext{
${ }^{96}$ Reigate v Union Manufacturing Co (Ramsbottom) Ltd [1918] 1 K.B. 592; Gerard, Fowler v Commercial Timber Co [1930] 2 K.B. 1.

97 Council Directive 2001/23/EC of 12 March 2001 on the approximation of the laws of the Member States relating to the safeguarding of employees' rights in the event of transfers of undertakings, businesses or parts of undertakings or businesses [2001] OJ L 82.

${ }^{98}$ The TUPE Regulations replaced the Transfer of Undertakings (Protection of Employment) Regulations 1981 (SI 1981/1794) ('old TUPE'), which implemented the European Acquired Rights Directive 77/1987. The adoption of the old TUPE has been highly controversial: see David Waddington MP, Under-Secretary of State for Employment, HC Debates, vol. 14, col. 680; R Eldridge, 'TUPE Operated to Damage Rescue Culture' (2001) Sept. Recovery 21; S Frisby, 'TUPE or not TUPE? Employee Protection, Corporate Rescue and "One Unholy Mess"' (2000) 3 CFiLR 249.

${ }^{99}$ C-135/83 Abels [1985] ECR 469.

${ }^{100}$ Nokes v Doncaster Amalgamated Collieries [1940] AC 1014 (HL).
} 
contracts are still transferred, but certain of the transferor's debts do not pass over to the transferee [regulations 8(1) - (6)].

27.74 Despite having been criticised by the doctrine, ${ }^{101}$ the author considers that TUPE Regulations strike an appropriate balance between conflicting interests. ${ }^{102}$ Autonomy of the parties is somehow preserved, as insolvency officers can always dismiss employees if the dismissal is justified by economic, technical or organisational reasons, ${ }^{103}$ but not if the main justification is to make the business more attractive to would be purchasers ${ }^{104}$ (regulation 7(2-4)). Additionally, the buyer can vary the contractual terms of the transferring employees if these changes are designed to safeguard employment opportunities and are approved by appointed representatives of the affected workers (regulation 9). Statutory provisions prescribe a compulsory outcome (transfer of the employees) only when there is a high likelihood that dismissal would be unfair or unjust. Even in this case, parties are free to rebut this presumption.

27.75 The main issues arise over the interpretation given by the courts of the statutory text. In particular, the author believes that cases like OTG V Barke, ${ }^{105}$ Key2 Law (Surrey) LLP106 and Crossroads Caring Scotland Ltd v McGuire ${ }^{107}$ have been wrongly decided ${ }^{108}$ as they assumed that administration procedures always fall in the category of formal insolvency procedures not aimed at the liquidation of the debtor.

\footnotetext{
${ }^{101}$ The criticism was in particularly directed to the pre-2006 version of the TUPE Regulations: D Pollard, 'Insolvent Companies and TUPE' (1996) 25(3) Industrial L.J. 191;

102 On the same vein: C Villiers, 'Employees as Creditors: A Challenge for Justice in Insolvency Law' (1999) 20(7) Comp. Law. 222 (with reference to the pre-2006 version); and C Nyombi, 'Employees' Rights During Insolvency' (11/2013) 55(6) Intl. J. Law \& Management 417 (with reference to the amended version). ${ }^{103}$ Kavanagh V Crystal Palace FC 2000 Ltd [2013] EWCA Civ 1410, [2014] 1 All ER 1033 commented among others by R Mundy, 'TUPE and Mental Gymnastics' (2014) 7(1) C.R. \& I. 31; S Brookes and C Davies, 'TUPE Restrictions in Administrations' (2014) 152(1445) Accountancy 48. In fact, pursuant to s.99, Sch. B1, IA 1986, the administrator has a short, 14-day window from the appointment to dismiss employees.

104 Spaceright Europe Ltd v Baillavoine [2011] EWCA Civ 1565, [2012] 2 All ER 812.

105 According to OTG Ltd v Barke [2011] IRLR 272 (EAT), which overruled a previous judgment in Oakland $v$ Wellswood (Yorkshire) Ltd [2009] ILRL 250 (EAT), the absolute approach has to be preferred over the fact-specific approach because it is conductive to legal predictability and preserves the EU directive's primary goal to protect the employees would be seriously dented.

106 Key2Law (Surrey) LLP v De'Antiquis [2011] EWCA Civ 1567, [2012] BCC 375.

107 Crossroads Caring Scotland Ltd v McGuire EAT(SC) 2014 WL 10653819.

${ }^{108}$ Against: L Robertson, 'To TUPE or not to TUPE' (2011) 3 C.R. \& I. 97.
} 
27.76 In the author's view, the interpretation given in previous cases, ${ }^{109}$ which stressed the need to adopt an approach that was in tune with the 'rescue' spirit of insolvency legislation, would better preserve the established principles of party autonomy.

27.77 With reference to financial collaterals and the payment and securities settlement systems, rules have been imposed by the European institutions ${ }^{110}$ and implemented by means of the Financial Collateral (No. 2) Regulations 2003 (SI 2003/3226). This law invalidates some insolvency law provisions (including those on moratorium and the administrator's disclaimer powers) with reference to these specific contracts.

27.78 As a result, netting and close-out arrangements are always admissible, if the lender demonstrates the existence of the collateral. This is because both the domestic and the European legislator shared the view that the integrity of the financial system is more important than the individual interests of the creditors in the insolvency procedure.

27.79 While it is debatable whether the directives achieved the intended, original purpose (i.e. to /limit systemic risk and promote integration and cost-efficiency of the financial market), ${ }^{111}$ what cannot be questioned is that party autonomy is protected. This legislative choice is perfectly consistent with the general rule on the treatment of executory contracts and it is likely to remain unaffected in the process of withdrawal of the United Kingdom from the European Union ('Brexit').

\section{(3) Contractual Remedies Negotiated by the Parties in Solvent Times}

27.80 If parties were always free to determine the outcome of their contractual relations in insolvency, this free-for-all approach may lead to abusive commercial practices by strong or institutional creditors at the expenses of general suppliers and consumers.

27.81 This sub-section investigates the matter of termination clauses, also known as ipso facto clauses. These are contractually negotiated provisions which permit the termination of a contract due to the insolvency of one of the contracting parties. This section also

\footnotetext{
${ }^{109}$ See Re Allders Department Stores Ltd (in Admin.) [2005] EWHC 172 (Ch), [2005] 2 All ER 122 and Re Huddersfield Fine Worsteds Ltd [2005] EWCA Civ 1072, [2005] 4 All ER 886 commented by A Walters, 'The Impact of Employee Liabilities on the Administrator's Decision to Continue Trading' (2005) 26(11) Comp. Law. 321.

${ }^{110}$ Recital 5 of the Directive 2002/47/EC of the European Parliament and of the Council of 6 June 2002 on financial collateral arrangements [2002] OJ L 168/43 (FC Directive), and Directive 98/26/EC of the European Parliament and of the Council of 19 May 1998 on settlement finality in payment and securities settlement systems [1998] OJ L 166/45.

${ }^{111}$ Recitals 1 and 3, FC Directive.
} 
investigates the treatment of non-assignment clauses to determine their compatibility with the general principles of party autonomy, freedom of contract and legal predictability.

\section{Ipso Facto Clauses}

27.82 Under English law, these arrangements are upheld upon insolvency, provided that the negotiated clauses do not breach the 'anti-deprivation principle'.112 The interaction between this principle and the general enforceability of ipso facto clauses results in a significant limitation to the right of the parties to make abusive use of their preinsolvency rights.

27.83 Beside these cases, courts are generally willing to uphold the validity and enforceability of 'ipso facto'113 and flip clauses.114 Close-out nettings ${ }^{115}$ (outside financial contracts) however, may come under scrutiny if they occur after the debtor has filed for insolvency.

27.84 The afore-mentioned Insolvency (Protection of Essential Supplies) Order 2015 represents a significant departure from this established approach. However, as discussed before, a more accurate analysis proves that such a departure is less radical than it appears at first sight.

27.85 The English understanding of ipso facto and similar clauses has cross-border implications. As shown in Pan Ocean, despite the recognition of the Korean rehabilitation proceedings as foreign main proceedings pursuant to the Cross-Border Insolvency Regulations 2006, the English court refrained itself from issuing an injunction restraining Fibra from terminating the contract when the English court could not itself have made such an order (i.e. invalidating the ipso facto clause) in its own domestic proceedings. ${ }^{116}$

\footnotetext{
112 Common-law rule which renders an arrangement void if it has the effect of removing an asset from an insolvent entity that would otherwise be capable of realisation for the benefit of the entity's creditors. See Belmont Park Investments Pty Ltd v BNY Corporate Trustee Services Ltd \& Anor [2011] UKSC 38, [2012] 1 AC 383 and IF Fletcher, The Law of Insolvency (5 $5^{\text {th }}$ edn, Sweet \& Maxwell: London, 2017) 771-777. 113 Revenue and Customs Commissioners v Football League Ltd [2012] EWHC 1372 (Ch), [2012] Bus LR 1539.

114 Flip clauses are contractually negotiated provisions which alter the right to a priority of payment among the contracting parties by reason of an insolvency event. 115 Close-out nettings are risk-mitigation tools used by financial institutions to offset mutual obligations whenever a termination event occurs. Lomas v Firth Rixson Inc [2012] EWCA Civ 419, [2012] 2 All ER (Comm) 1076.

116 Re Pan Ocean Co. Ltd [2014] EWHC 2124 (Ch), [2014] Bus LR 1041. The applicant, the administrator of a company which has filed for insolvency relief in South Korea, sought an order to refrain the counterparty from terminating a contract which included an ipso facto clause and was subject to English law. Such a clause would have been voided under Korean law and the relief granted. Distancing themselves
} 
In other words, the fact that the relevant termination provisions were invalid "as a matter of Korean law" was irrelevant: it was the English anti-deprivation principle, not any Korean law rule, which should have governed the validity of the termination provisions. ${ }^{117}$

\section{$\underline{\text { Non-Assignment Clauses }}$}

27.86 Should the law impose limits on the abilities of the contracting parties to prevent the assignment of receivables arising from a contract to a third party?

27.87 At first glance, the answer should be in the negative, as the ability to negotiate such clauses is a clear expression of the principle of party autonomy. However, there are some concerns that this freedom, if unregulated, may result in abusive practices and unfair competitive advantages for large retailers and distributors against smaller companies in the supply chain. In fact, by inserting non-assignment clauses in their contracts, large companies restrict the suppliers' ability to raise finance by using their receivables as collaterals and fencing themselves from aggressive credit recovery practices by any potential assignees.

27.88 S.1 of the Small Business, Enterprise and Employment Act 2015 allowed regulations to be used to invalidate clauses that prevent the assignment of receivables. In the legislature's mind, these regulations would have applied only to selected contracts where one of the parties was a SME. However, the proposed Business Contract Terms (Assignment of Receivables) Regulations $2017^{118}$ went far beyond that, as it proposed a general ban on non-assignment clauses that would apply to all but the excluded contracts and irrespective of the nature and size of the businesses involved in the transaction.

27.89 The consultation that followed was marked by the widespread criticism by the industry. The government was cautioned about the potential consequences for several sectors of the economy (in particular, construction and cross-border contracts) caused by the introduction on a general ban on non-assignment clauses. Respondents contested the

from the U.S. approach in Re Condor Insurance Co. Ltd (2010) 601 F 3d 319, the court refused to issue such an order.

117 R Matthews, 'Tough Choices: Ipso Facto, the Anti-Deprivation Principle and Choice of Laws' (2015) 30(2) JIBLR 62, 63.

${ }^{118}$ Available at

<https://www.legislation.gov.uk/ukdsi/2017/9780111160305/pdfs/ukdsi_9780111160305_en.pdf> accessed 8 September 2018. 
lack of consideration for the long-standing English principle of freedom of contract and highlighted the risks for insolvency practice, as the rights of set-off for creditors and the insolvent debtor would then be significantly restricted. ${ }^{119}$

27.90 Following a persuasive paper written by the City of London Law Society,120 the government withdrew the bill from Parliament, but it still seems that it intends to present a new proposal in the course of 2018.121 The industry does not seem persuaded that the new proposal would properly consider the observations, which have emerged in the course of the 2017 consultation. ${ }^{122}$

\section{(4) Concluding Remarks}

27.91 This cursory analysis of the most significant exceptions to the general continuation rule in the treatment of executory contracts has proven that - with the sole remarkable exceptions of the judicial interpretation of employment provisions and the proposed legislation on non-assignment clauses - English insolvency law is consistent with the principles of party autonomy, freedom of contract and legal predictability.

27.92 In their attempt to strike a balance between opposing interests, the highly skilled English judiciary produced a significant number of judicial precedents. Navigating through them may be extremely challenging for experienced practitioners and academics, let alone for anybody else. It might therefore be questioned if the current system really preserves these values. However, this is a question for further studies.

\section{Reforms}

27.93 Three aspects have to be considered to understand the existing law and its evolution:

\footnotetext{
${ }^{119}$ R Calnan, 'Ban the Ban: Prohibiting Restrictions on Assignment of Receivables' (March 2015) JIBFL 136.

${ }^{120}$ Available at: <http://www.citysolicitors.org.uk/attachments/category/117/CLLS\%20\%20Note\%20to\%20BEIS\%20on\%20Business\%20Receivables\%20legislation\%20\%2020\%2011\%2017.pdf> accessed 8 September 2018.

121 Herbert, Smith, Freehills LLP, England and Wales. Preview of 2018 (January 2018) 15.

122 Allen \& Overy, 'Why the Proposed UK Regulation Prohibiting Non-Assignment Clauses is Bad' (16 January 2018)

<http://www.allenovery.com/SiteCollectionDocuments/Why\%20the\%20proposed\%20UK\%20regulatio n\%20prohibiting\%20non-assignment\%20clauses\%20is\%20bad.pdf> accessed 8 September 2018.
} 
1. the long-established pro-creditor ${ }^{123}$ approach to insolvency cases, rooted on the centrality of the principles of party autonomy, sanctity of contracts and promotion of legal predictability;

2. the eagerness shared by all recent governments to have the country ranking at the top of the World Bank's annual Doing Business Reports; ${ }^{124}$ and

3. 'Brexit' and the resulting aspiration to promote the country as a global hub for rescue proceedings.

27.94 While the second and third aspects justify the recent attempts to promote a pro-rescue, pro-debtor culture in the country, they invariably collide with the first axiom. This explains to a certain extent why some proposals for reform - such as those to extend an automatic moratorium in CVAs to medium and large sized companies - have not fell on fertile ground.

27.95 First suggested in 2009125 , the proposal to extend the moratorium to medium and large enterprises entering into a CVA failed to result in a bill due to the termination of the Labour legislature and the disapproving replies from the industry. Less than one year passed before the newly appointed government issued a new consultation, ${ }^{126}$ which did not significantly differ from the previous paper in terms of the content. Unsurprisingly, in analysing the responses received from the industry, the then Under-Secretary of State for BIS had to admit "that, while the refinancing and restructuring of company debt

\footnotetext{
${ }^{123}$ The distinction between pro-debtor and pro-creditor jurisdictions comes from PR Wood, Principles of International Solvency (Sweet and Maxwell: London, 1995). It is acknowledged that these labels tend to over-simplify an otherwise very complex classification problem. As a general rule, pro-creditor systems tend not to infringe significantly on the rights bargained by creditors in solvent times. On the opposite end of the spectrum, pro-debtor systems erode those rights whenever it appears to be appropriate to achieve the rehabilitation of the distressed business. Among others: M Pomerleano and W Shaw, Corporate Restructuring. Lessons from Experience (The World Bank: Washington D.C., 2005) 308. For a challenge to the standard characterization as U.S. law being 'pro-debtor' and U.K. law being 'pro-creditor', see: G McCormack, 'Apples and Oranges? Corporate Rescue and Functional Convergence in the US and UK' (2009) 18 Int. Insolv. Rev. 109.

${ }^{124}$ In all recent consultations, the proposed reforms were designed to make England the best place in the world to start and grow a business, while the Conservative Party 2015 manifesto included the promise to achieve the highest ranking in Europe and a place in the top five countries in the world in the World Bank's annual Doing Business Report.

125 The Insolvency Service, Encouraging Company Rescue (June 2009),

<http://webarchive.nationalarchives.gov.uk/20140311023846/http:/www.insolvencydirect.bis.gov.uk/i nsolvencyprofessionandlegislation/con_doc_register/compresc/compresc09.pdf> accessed 8 September 2018.

126 The Insolvency Service, Proposals for a Restructuring Moratorium: A Consultation (June 2010) <http://webarchive.nationalarchives.gov.uk/+/http:/www.insolvency.gov.uk/insolvencyprofessionandle gislation/con_doc_register/RestructuringMoratoriumConsultationDocument.pdf $>$ accessed 8 September 2018.
} 
remains a valid concern, the urgency of the case for introducing such a moratorium is not as great as previously thought" ${ }^{127}$

27.96 The government's eagerness to promote corporate rescue has been successful in other, more limited and less controversial initiatives. Following the enactment of the Enterprise and Regulatory Reform ('ERR') Act 2013, the government succeeded in preventing essential utility and IT suppliers ${ }^{128}$ from withdrawing their supplies to businesses admitted to CVAs or administration.

27.97 However, the mixed replies from the industry in the ensuing consultation, ${ }^{129}$ as well as the awareness that " $[\mathrm{t}]$ he freezing or stay on self-help termination is unquestionably one of the most draconian and controversial of all stays, because of its massive impact on transactions", ${ }^{130}$ pushed the government to adopt a more cautious approach than it had previously envisaged.

27.98 On one hand, no obligations of such kind have been extended to card payment providers and the list of "essential suppliers" has been made exhaustive. On the other, suppliers were granted the right to ask for additional safeguards - even of personal nature - from the debtor to continue their business.

27.99 More remarkable results have been achieved in the reform of the new Insolvency Rules 2016 published on 25 October 2016, which was entered into force on 6 April 2017. Significant proposals for the purposes of this study have been included in the 2016 consultation A Review of the Corporate Insolvency Framework. ${ }^{131}$ A more recent consultation focused on improving corporate governance aspects in insolvency and

\footnotetext{
127 Written Ministerial Statement, 11 May 2011.

${ }^{128}$ Even though supplier of communications services by a provider of a public electronic communications service were already prevented from discontinuing their services by virtue of the Communications Act 2003.

129

<https://www.gov.uk/government/uploads/system/uploads/attachment_data/file/402336/responsesmerged.pdf> accessed 8 September 2018.

130 PR Wood, Principles of International Insolvency (2 ${ }^{\text {nd }}$ edn, Sweet \& Maxwell: London, 2007); R Suchak,

"Corporate Rescue Proceedings and the Enforcement of Ipso Facto Termination Clauses: A Comparison of the English and US Approaches" (2011) 8(2) Int. C.R.

131 The Insolvency Service, A Review of the Corporate Insolvency Framework (May 2016)

<https://www.gov.uk/government/uploads/system/uploads/attachment_data/file/525523/A_Review_o f_the_Corporate_Insolvency_Framework.pdf $>$ accessed 8 September 2018.
} 
rescue cases ${ }^{132}$ and elusive fiscal practices in insolvency. ${ }^{133}$ They are, therefore, less relevant for the purposes of this work.

27.100 The 2016 paper proposed to enhance the protection of essential agreements by giving the company the right to designate some contracts as essential. The enhanced protection would last for the duration of the restructuring moratorium (proposed in the same consultation), the subsequent CVA or administration procedure, and would be available to businesses entering into an alternative restructuring plan (equally proposed for the first time in the same paper).

27.101 The government was aware that these provisions would have significantly impaired the autonomy of the parties. Therefore, it envisaged specific protections for the suppliers and the opportunity for courts to reject the debtor's designation if the provision was not essential and alternative arrangements could be made at a reasonable cost and within short notice.

27.102 Following the analysis of the responses to the consultation, the government decided to abandon the original proposal and, instead, legislate to prohibit the enforcement of termination clauses on the ground that one of the parties has entered into a formal insolvency procedure. ${ }^{134}$

27.103 This would seem to be a significant shift towards a pro-debtor, U.S.-informed approach to the treatment of termination clauses, similar to regulatory changes recently introduced in Australia. ${ }^{135}$ However, the government recognised that suppliers would still be able to terminate their contracts on other grounds (such as delays in the payment of outstanding invoices). This ban would not be applicable to financial products and services. With reference to licenses, it would apply only to contractual licenses but not to those granted

\footnotetext{
132 The Insolvency Service, Insolvency and Corporate Governance (20 March 2018) $<$ https://assets.publishing.service.gov.uk/government/uploads/system/uploads/attachment_data/file/6 91857/Condoc_-_Insolvency_and_Corporate_Governance_FINAL_.pdf> accessed 8 September 2018. 133 HM Revenue \& Customs, Tax Abuse and Insolvency: A Discussion Document (11 April 2018) <https://assets.publishing.service.gov.uk/government/uploads/system/uploads/attachment_data/file/6 98173/Tax_Abuse_and_Insolvency_A_Discussion_Document.pdf> accessed 8 September 2018. ${ }^{134}$ Department for Business, Energy \& Industrial Strategy, Insolvency and Corporate Governance: Government Response (26 August 2018) 59-63 <https://assets.publishing.service.gov.uk/government/uploads/system/uploads/attachment_data/file/7 36207/ICG_-_Government_response_doc__24_Aug_clean_version_with_Minister_s_photo_and_signature_AC_final.pdf> accessed 8 September 2018. ${ }_{135}$ E Streten, National Report for Australia, in J Chuah and E Vaccari (eds). Treatment of Executory Contracts in Insolvency Law: A Transnational Study (EE Publishing: Cheltenham, 2019).
} 
by public authorities, as there may be legitimate public policy grounds to remove these licenses on the insolvency of a company.

27.104 It follows therefore that, even if enacted in the form envisaged in the government's response to the 2016 consultation, the proposed changes to the treatment of executory contracts and termination clauses would not in themselves determine the reversal of the established creditor-centred policy that has insofar characterised English insolvency law.

\section{E. Concluding Remarks}

27.105 The treatment of executory contracts in insolvency during the last two decades has been extremely unstable. Furthermore, as suggested by some commentators, ${ }^{136}$ the decision to withdraw from the European Union and the regulatory reforms undertaken in other countries $^{137}$ risk to compromise the country's reputation of being at the forefront of international corporate restructurings.

27.106 Some of the apparent confusion arises from an inadequate understanding and study of the principles that undergird the current insolvency law. Legal provisions appear more as a reaction to circumstances and high-profile cases rather than as a result of principled planning.

27.107 This perception is misleading. Less recent reforms, consultations and proposals including the 'Graham Report'138 - have favoured the implementation of changes aimed at preserving the generally accepted principles of party autonomy (both before and after the commencement of a formal insolvency procedure), freedom of contract and legal predictability. These principles informed what is commonly known as the English creditor-friendly approach to the management of insolvency cases.

\footnotetext{
${ }^{136}$ R Paterson, 'Winds of Change: Corporate Insolvency and Proposed Reform' (2018) 11(1) C.R. \& I. 17. 137 Such as Singapore. See, among others: G McCormack G and W Yee Wan, 'Transplanting Chapter 11 of the U.S. Bankruptcy Code into Singapore's Restructuring and Insolvency Laws: Opportunities and Challenges' (2018) J. Corp. L. Stud. (1473-5970) 1.

138 Teresa Graham CBE, Graham Review into Pre-pack Administration (The Insolvency Service, 2014), <https://www.gov.uk/government/publications/graham-review-into-pre-pack-administration> accessed 8 September 2018.
} 
27.108 More recent consultations ${ }^{139}$ and the government's response to these exercises ${ }^{140}$ seem to mark a significant shift towards the adoption of a more debtor-friendly approach. This paper has argued that - at least with reference to termination clauses - party autonomy, freedom of contract and legal predictability are preserved. Nevertheless, if enacted in conjunction with other measures, such as the proposed restructuring moratorium and the flexible restructuring plan, they may have the potential to significantly alter this fragile equilibrium.

139 The Insolvency Service, A Review of the Corporate Insolvency Framework (May 2016)

<https://www.gov.uk/government/uploads/system/uploads/attachment_data/file/525523/A_Review_o f_the_Corporate_Insolvency_Framework.pdf> accessed 7 March 2018; The Insolvency Service, Insolvency and Corporate Governance (20 March 2018)

<https://assets.publishing.service.gov.uk/government/uploads/system/uploads/attachment_data/file/6 91857/Condoc_-_Insolvency_and_Corporate_Governance_FINAL_.pdf> accessed 8 September 2018.

140 Department for Business, Energy \& Industrial Strategy, Insolvency and Corporate Governance: Government Response (26 August 2018)

<https://assets.publishing.service.gov.uk/government/uploads/system/uploads/attachment_data/file/7 36207/ICG_-_Government_response_doc_-

_24_Aug_clean_version_with_Minister_s_photo_and_signature_AC_final.pdf> accessed 8 September 2018. 